\title{
UK debates public's role in science advice
}

[LONDON] The British government has been presented with conflicting advice on the extent to which consumers and other public representatives should be involved in advising on regulations on the monitoring and control of genetically modified (GM) crops.

The government's ruling is planned to be published today (20 May) as part of a package of measures intended to calm public fears about such crops, while demonstrating that such concerns are being taken into account.

Last week, the House of Commons Environmental Audit Select Committee issued a report in which it proposed that members of the public should be appointed to the government bodies that are responsible for overseeing the safety of such crops. The committee argued that this would ensure that the scientific advice provided to ministers was tempered with ethical and consumer concerns.

On Tuesday of this week, however, the House of Commons Science and Technology Select Committee issued its own report on the role of science advice in regulating such crops. It argued that the make-up of scientific advisory committees should merely include suitably qualified experts from "other, not necessarily scientific, disciplines".

While also using the term "lay member" to describe such experts - whose role would

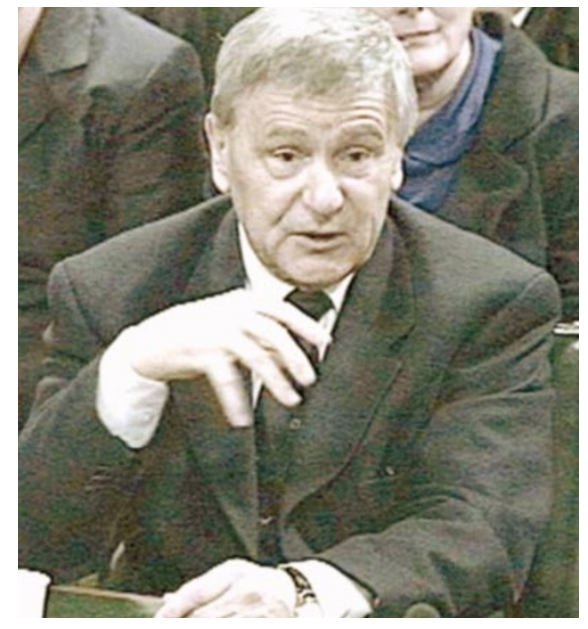

Hero or villain? Arpad Pusztai tells the select committee of his concerns over GM crops.

be "to ensure that the evidence is subjected to a sufficiently questioning review from a wide-ranging set of viewpoints" - the science select committee emphasizes that scientific advice should be offered free of any direct input from environmentalist or consumer representatives.

"Scientific advice must not be tinged with ethical and consumer concerns," says Michael Clark (Conservative, Rayleigh), the

\section{Royal Society: GM food hazard claim is 'flawed'}

[LONDON] Britain's Royal

Society announced this week that it has found no convincing evidence of adverse health effects from eating genetically modified (GM) potatoes in unpublished data from research at the Rowett Research Institute in Scotland.

The work was carried out by Arpad Pusztai, a senior researcher at the institute, who claimed to have detected a potential impact of such food on the immune system. This caused a nationwide controversy last year when it was described on a television programme (see Nature 394, 714; 1998 \& 397, 547; 1999).

But a scientific panel set up by the society says that, on the basis of the information available to it, the work appears to be "flawed in many aspects of design, execution and analysis". The panel adds that no conclusions should be drawn from it.

Pusztai told the panel that further data exists beyond that which was included in the review of his work. But he failed to produce such data or other evidence.

The panel's conclusions were published in a report on the Pusztai data and on toxicity in GM foods. The panel says that the slight differences that Pusztai claimed to have detected between rats fed predominantly on GM and non-GM potatoes could not be interpreted, because of the technical limitations of the experiment and incorrect use of statistical tests.

The panel also points out that, even if the experiment had been done skilfully, it would not be justifiable to draw conclusions about whether GM foods generally are harmful to human beings. "Each GM food must be assessed individually," says the report.

Problems with the Pusztai data include a relative lack of information on how the GM and control diets differed in detailed composition. The GM potatoes used contained almost 20 per cent less protein than unmodified potatoes, and rats in the long-term feeding study were given additional protein to avoid starvation. The Royal Sociaty panel suggests that the observed effects could have been caused by the supplementary diet being inadequate or incomplete. Its report says that Pusztai's work attempted to cover too much ground with the information available.

The society says its review of internal Rowett institute documents was "entirely appropriate" given that these are now in the public domain. Natasha Loder chairman of the committee. "Scientists should concentrate on the science."

Such sentiments are reflected in the strong criticism the committee makes of press coverage of the potential impact of GM crops, including, for example, the prominent claims made by some newspapers about a link between increased antibiotic resistance - caused by the continued presence of antibiotic markers - and diseases such as meningitis (see Nature 397, 637; 1999).

To counter such reporting, the committee recommends that media coverage of scientific matters should be governed by a code of conduct "which stipulates that scientific stories should be factually accurate". It suggests that breaches of any such code of practice should be referred to the Press Complaints Commission.

The conclusions of both parliamentary reports were being studied this week by Jack Cunningham, the cabinet minister responsible for co-ordinating the government's response to the public outcry over GM crops, as he prepared to announce his decision on new regulatory arrangements today.

Prominent among these is expected to be some form of overarching body, bringing together the responsibilities of several existing advisory bodies, such as the Advisory Committee on Releases to the Environment, and the Advisory Committee on Novel Foods and Processes.

Also before Cunningham will be the results of a scientific inquiry carried out by a panel set up by the Royal Society into preliminary results revealed last year by Arpad Pusztai, a researcher at the Rowett Research Institute in Scotland. The panel found no evidence to confirm Pusztai's claim that his research indicated a potential threat contained in GM foods to the human immune system (seeleft).

Commenting on press coverage of the Pusztai affair, the Commons science committee - whose inquiry into GM foods forms part of a wider inquiry into the role of scientific advice in government - emphasizes the need to respect the crucial role played by the peer-review process.

"Those who start telling the media about alleged scientific results that have not first been thoroughly scrutinized and exposed to the scientific community serve only to mislead, with potentially very damaging consequences," says the committee's report.

The report also prompts the government "to establish international agreement on what constitutes a 'valid' scientific reason" and to ensure that "the definition of validity is based on the precautionary principle". This is an implicit reference to disputes such as that between Europe and the United States on labelling food produced using GM techniques (see Nature 398, 641; 1999). 